\title{
Using English Movie as an Attractive Strategy to Teach Senior High School Students English as A Foreign Language
}

\author{
Maria Asumpta Deny Kusumaningrum
}

\begin{abstract}
The major purpose of this paper is to reveal how to implement English movies in teaching English as foreign Language to senior high school students. English as Foreign Language is implemented as the compulsory subject to learn in senior high school in Indonesia. Unfortunately, beyond the implementation, the fact that not all pupils enjoy learning English occurs. Realizing that fact, teacher should find a strategy to attract students' attention to learn EFL. Moreover, using English movies to teach English can be the answer. In the application, teacher can use English movies to teach four skills. They include listening, speaking, and also writing skills. By using English movies, teacher can also teach grammar and introduce new vocabulary to students. Furthermore, the belief that everyone loves watching movies strengthens the teacher's confidence to use English movies as an attractive strategy to teach English as a Foreign Language to senior high school Students.
\end{abstract}

Keywords: English movies, English as a Foreign Language, four skills

\section{A. INTRODUCTION}

English as a Foreign Language is implemented as the compulsory subject to learn in senior high school in Indonesia. The aim of the implementation is to achieve the informational level of literacy which expects students to be able to use English to access accumulated knowledge and use English in informal and formal contexts.

$$
\text { Unfortunately, beyond the }
$$
implementation, the fact that not all pupils enjoy learning English occurs. Besides learning a new language, the existing teaching method which merely transfer knowledge takes part in forming the stressful environment to students. Considering the boredom atmosphere experienced by students during the teaching and learning process, the knowledge cannot be received effectively. Moreover, the goal of the teaching and learning process will not be achieved.
To answer this problem, senior high school teacher is expected to find a creative strategy to apply in the teaching and learning process. Teacher is challenged to be able to apply an attractive strategy in his/her English class. There are some ways to make an attractive teaching and learning process. Teacher can use flash cards and English songs to teach and involve students to learn English. However, there is another fun strategy to implement in teaching English to senior high school Students in Indonesia, namely through using English movies.

By using English movies to teach English, teacher does not only facilitate a visual or audio aid to students, but teacher also facilitates them with both audio and visual elements at the same time. Besides, teacher can use a movie to teach students several skills including listening, speaking and writing. Other benefits in implementing English movies in teaching and learning 
process can also be gained. In addition, the belief that everyone loves watching movie strengthens the teacher's confidence to use English movies as an attractive strategy to teach English as a Foreign Language to senior high school Students.

An inappropriate strategy implemented in teaching English as a Foreign Language to senior high school students often comes as a problem. The teacher-centered way of teaching which usually occurs in class in which teacher merely transfers knowledge without considering senior high schoolstudents' attention span is ineffective. The following assignments or quizzes make them bored during the teaching and learning process. The boring environment experienced by senior high school students, therefore, contributes to the level of success students experience in learning.

It was explained earlier that English movies facilitates teacher to teach several skills at the same time, including listening, speaking, and writing, and also provides enjoyable learning environment in learning grammar and vocabulary. Therefore the major focus on this paper is how to implement English movies in teaching English as a foreign Language to senior high school students.

Considering the importance of an attractive strategy to teach senior high school students, this paper intends to address a question: How are English movies implemented to teach English as a foreign language to senior high school students?

This paper is aimed at providing information about how English movies are used as an attractive strategy to teach English as a Foreign Language to senior high school students. This strategy of using English movies for teaching and learning activity also considers about its benefit. Therefore, this paper also states the benefits of using English movie as an attractive teaching and learning strategy.

\section{B. REVIEW OF LITERATURE}

As stated by Agustin in her paper entitled Competence, Process, and Assessment Standards: Towards autonomy in ELT, there are four literacy levels implemented in Curriculum Based Competence. They are performative, functional, informational, and epistemic level. Performative level is implemented in Elementary School, whereas functional level is applied in Junior High School. She goes on to say that informational level is implemented in Senior high school whereas epistemic level is applied in University.

Since this paper focuses on the Senior high school, therefore informational level as the literacy level implemented in Senior high school will be discussed in depth. According to Agustin, in the informational level, learners are expected to:

- use English to access accumulated knowledge.

- use English in informal and formal contexts.

By considering the goal to achieve in teaching Senior high school students, teacher should be able to apply appropriate techniques and strategy. However, it is not an easy job for teachers. Besides focusing on the goal to reach, teachers should also pay attention to their students. As an example, teacher should be able to comprehend the characteristics of Senior high school students. By understanding the characteristics of students, teacher can maximize the success of teaching and learning process. As cited in www.ierg.net, Senior high schoolstudents generally have some characteristics, such as:

- They are interested in learning activities

- They need opportunities for selfexpression

- They want to take individual responsibility for learning and progress towards targets 
- They have attention span between eight to fourteen minutes.

Understanding the goal to achieve in Senior high school grade and general characteristics of the students, teacher can start to find, choose and apply an appropriate strategy to apply in teaching EFL to Senior high school students. One strategy that can be implemented in teaching EFL to Senior high school students is by using English movies. According to Louis Pugliese, a lecturer in Educational Psychology California State University, Northridge, movie is an exiting way to learn English, since it gives not only the matter of pronunciation, but also a lot of other unspoken parts of English language.

\section{DISCUSSION}

\section{The Implementation of English Movie in Class Activity}

To conduct an attractive English teaching and learning process for Senior high school students, teacher can use English movie. In the implementation, before teacher starts conducting teaching and learning activity by using western movie, there are some points to consider. The points are:

- First, teacher should consider the audience of English movie. Since the audiences of the movie are Senior high school Students, teacher is expected to choose the movie which is appropriate to watch. Directly, it insists teacher to watch first the movie for making sure whether the movie is suitable for students or not.

- Second, teacher should consider the content of the movie. Teacher should be careful to play movie containing certain religious or race issue. If teacher still wants to play the movie in any reasons, before turning the movie on, teacher can give some notes to students. It aims to avoid the misconception and misunderstanding among students in responding the movie.

- Third, teacher should consider the appropriateness between movie and the level of students. Since the movie will be played for Senior high school students, teacher can choose movie which does not contain too much slang words and idioms, except for some reasons. There are some English movies suggested to implement such as Groundhog Day, Freaky Friday and Nine to Five. Those movies are considered as suitable movies to use in teaching Senior high school students since besides they do not contain much slang, the movies are funny and easy to follow. Moreover, they also have deeper underlying messages which can lead to good discussions.

- Fourth, teacher should consider the relation between movie and the syllabus of Senior high school. Teacher should be creative in relating the movie and topic discussed based on the syllabus. For example, when the basic competence states the topic discussed is asking for information, teacher can play certain scene which shows how people ask for information. Thus, it is no doubt that the movie really supports the syllabus.

- Fifth, teacher should consider time of course and time needed to play the movie. Since it is Senior high school, time allocation for one meeting is 45 minutes. Let's say that in a certain day, English subject has 2 meetings. It means that the subject can be conducted in 90 minutes. By realizing that fact, it is almost impossible for teacher to play the entire movie. It is based on the consideration that commonly movie lasts for 90 minutes 
or more. If teacher still forces to play an entire movie, then there is no time for class discussion. Teacher should remember that teacher is not showing the movie, but by the movie teacher is teaching English to Senior high school students. Besides, it is possible for students to get bored. Because of that, teacher should choose a movie which less in less than 90 minutes, such as Mr. Bean the series. Another possibility is that teacher can only play several scenes which have strong correlation to the topic discussed in the meeting.

- Sixth, teacher should consider the existence of supporting media to play the movie. Before starting the lesson, teacher should make sure whether the supporting media such as computer set or LCD has already been provided or not; whether the supporting media can work well or not.

In the application, teacher can use English movies to teach four skills. They include listening, speaking, and also writing skill. By using English movie, teacher can also teach grammar and introduce new vocabulary for students.

\section{a. Listening Skill}

Since it is obviously seen that movie can produce audio elements, teacher can use English movie to teach Senior high school students listening skill. Moreover, in the implementation, teacher can divide class activity into three parts. They are pre-watching, while-watching, and postwatching. In pre-watching, teacher can ask students whether they have already known the movie or issues related to the movie they will watch. After doing the pre-watching, teacher can play the movie in the while-watching part. After watching the movie, teacher can post students worksheets containing some questions which are related to the movie. Furthermore, the implementation of those three parts can be seen in the following example:
Topic
: Narrative Text
Movie Title
: Groundhog Day

\section{Pre-Watching:}

Teacher delivers some questions orally to students about their knowledge of Groundhog Day tradition, such as :

1. Have you ever heard about Groundhog Day?

2. Do you know what country celebrating Groundhog Day?

3. Do you know when Groundhog Day is celebrated?

$>$ After students respond to the questions, teacher starts to introduce students the movie. For example, teacher can ask students some questions such as:

1. What will you do when you wake up in the morning, you find that it is the same day like yesterday and experience exactly the same events that happened the day before? Could you imagine it?

2. Do you know Bill Murray?

3. Have you ever watched Groundhog Day movie?

\section{While-watching :}

Teacher plays a movie entitled Groundhog Day.

$>$ Teacher plays the movie without showing its Indonesian subtitle.

$>$ Teacher asks students to take notes while watching movie.

\section{Post-watching :}

After watching the movie, teacher can start asking students' 
opinions about the movie. Teacher can ask, "What do you think about Groundhog Day movie? Is it interesting?"

Having heard students' responses, teacher leads to individual task for students.

Teacher distributes a worksheet containing some comprehension questions related to the movie. The worksheet can contain several questions such as:

1. What is Phil Connors' profession?

2. Where are Phil Connors and his team asked to go to cover Groundhog Day celebration?

3. What happens to Phil when he wakes up in the morning?

4. What does Rite suggest to do when Phil explains the situation to him?

5. What does Phil do during his stay in Punxsutawney Phil?

\section{b. Speaking Skill}

In addition to listening skill, teacher can use English movies to teach Speaking skill. Just like in listening skill, in its implementation, teacher can also divide the class activity into three parts. They are Pre-watching, While-watching, and Post-watching. Since the objective in speaking skill is for the students to be able to speak English accurately, fluently and contextually, teacher should focus more on students' speaking activities. For that reason, in post-watching, teacher can ask students to work in group. The implementation of the whole activity can be seen as follows:

Topic

: Narrative Text

Movie Title

: Mr. Bean in Room 426 Part 1

\section{Pre-Watching :}

Teacher asks the students about their experiences in the holiday, such as :

1. Where did you spend your last holiday?

2. What did you do in this place you went to?

3. How did you get there?

4. Who did you go with?

5. What was your most memorable holiday? Why?

After students respond to the questions, teacher starts to introduce students to the movie they will watch. For example, teacher can ask students some questions such as:

1. Do you know Mr. Bean?

2. Have you ever watched his movie?

3. Do you love watching $\mathrm{Mr}$. Bean's movie?

\section{While-watching :}

Teacher plays Mr. Bean's Movie entitled Mr. Bean in Room 426 Part 1.

Teacher plays the movie without viewing the Indonesian subtitle.

> Teacher asks students to take notes while watching the movie.

\section{Post-watching :}

$>$ After watching the movie, teacher can start to ask students' opinions about the movie. Teacher can ask, "What do you think about Mr. Bean's movie? Is it interesting? Funny?"

Teacher asks students to work in group of three and create dialogues for the receptionist, $\mathrm{Mr}$. Bean and the bellhop. After that, practice the dialogues among the receptionist, Mr. Bean and the bellhop. 
As the follow-up activity, teacher can ask some groups to perform the dialogues in front of the class. In responding to the performances, it is possible for the teacher to give several feedbacks in the students' pronunciation or diction.

In spite of the activity mentioned above, teacher can use English movies to teach some common expressions used in English, such as expressing happiness and sympathy. What teacher can do is choose and play certain scene showing any expressions of happiness or sympathy. Then, teacher can ask students to find the expressions of happiness or sympathy as many as possible in the scene. After that, based on the expressions they got, students can work in pair and make a short conversation.

\section{c. Writing skill}

By using English movies, teacher can also teach writing skill. In writing skill, teacher still can implement the same movie like in speaking skill, which is Mr. Bean in Room 426 Part 1. Teacher can also implement same activities of pre-teaching and whilst-teaching such as in speaking skill. However, in the postwatching, students can have different assignment to do. For example, each student has to construct writing as the summary of Mr. Bean in Room 426 Part 1 movie. If time is limited for students to accomplish it, then they can continue writing at home based on the notes they took while watching the movie.

As the follow-up activity, students can work in pair and do peer-editing in order to check the correctness of grammar, diction, spelling and other minimum requirements in writing.

\section{d. Grammar}

It is obviously seen that by using English movies, teacher can teach listening, speaking and writing skill. Nevertheless, in spite of those three skills, teacher can also use English movies to teach grammar. For Senior high school students, learning English grammar has its own challenge. Since there are many grammar rules to remember, students often experience stress. In addition, grammar teaching which focuses only on the grammar theory and exercises will rob the students of the chance to have fun grammar learning.

The stressful environment, therefore, influences negatively on their successto receive the lesson. Students who are already in stressful and boredom environment will not be easy to receive the lesson. If they are bored, unconsciously, they will refuse the lesson. Then, they will ignore the lesson and prefer to do an activity they like, such as falling asleep in the middle of lesson, chit-chatting with friends, or even skipping the class. Realizing that fact, teacher should find a strategy to attract students' attention to learn grammar. Moreover, using English movies to teach English grammar can be the answer.

Still using the same movie like in speaking and writing skill, $M r$. Bean in Room 426 Part 1, teacher can teach sentences using 'going to'. What teacher needs to do is playing the movie and before another event comes in the scene, teacher can pause the movie and ask, "What is Mr. Bean going to do?" Then, teacher can lead a class discussion based on it. Besides teacher can also teach tenses such as present continuous by using English movies. For example, after several times, teacher pauses the movie and ask to students, "What is Mr. Bean doing?" Following the question, teacher can start to teach present continuous based on the movie, for example by 
producing the sentence: "Mr. Bean is driving on his yellow car" and after that analyzing the structure of sentence.

\section{e. New vocabulary}

Implementing English movies in teaching English as a Foreign Language to Senior high school students can also improve students' vocabulary. Students not only get fun learning environment, but they also get new vocabulary from the movie they watch.

Teacher can conduct teaching vocabulary by playing English movies without showing the Indonesian subtitle. Teacher can also ask students to write strange words in the movie for them. After watching the movie, teacher can ask some students to share what new words they learned from the movie. Following the activity, and as the individual task, teacher asks students to find the Indonesian meaning of the new words.

However, in the implementation, teacher can also make word specification in teaching vocabulary. For example, teacher can use movie entitled Groundhog Day. The main character in the movie, Phil Connors, works as a meteorologist. Based on the information from the movie, teacher can ask students, "What is Phil Connors' profession?" After that, teacher can begin to introduce other professions.

\section{f. Advantages}

Using English movies can be an attractive strategy to teach English as a Foreign Language to Senior high school students. It can be used to teach listening, speaking and writing skill. Besides, it provides fun learning environment to teach grammar and vocabulary to students. In the application, there are some other benefits to gain. They are:
1. English movies present more natural language, since the speakers in the movie are native speakers. Because of that, students can learn how to pronounce the words appropriately.

2. English movies provide students a lot of contexts which can help them to learn how to use such expressions appropriately and contextually.

3. Students love watching movies. Fun learning environment gives them motivation to learn English as a Foreign Language.

4. Students can also learn English culture. While watching English movies, students can see cultural aspects included in the plot to illustrate social customs such as table manners to weddings and funerals, holidays, and celebrations. Thus, students' understanding in cross cultural communication is also improved.

\section{g. Disadvantages}

Besides giving some benefits, the implementation of English movies in teaching EFL to students also gives some disadvantages. They include:

1. While the movie is playing, students try to understand word by word instead of the main point of the movie. This may frustrate the students. Therefore, before playing the movie, teacher should explain clearly what the students have to do. Thus, students can enjoy watching the movie and learning English at the same time.

2. If the movie takes too much time to play, it is possible that students will get bored. To anticipate that, teacher should consider the length of the movie to watch or break the movie into several segments. 
3. English movies can be American or British movies to give students different varieties of English. Different varieties entail different pronunciation and vocabulary. These differences may make students confused. Therefore, before or after watching the movie, teacher can explain or lead a class discussion about the English variety used in the movie.

4. The limited facilities in school can also pose an obstacle in teaching EFL using movies. If school has an English laboratory, then teacher can play the movie in the lab. However, if the school does not have an LCD or big screen TV, it is almost impossible to play the movie in the class. In addition, the activity might disturb the teaching and learning process of other classes.

\section{CONCLUSION}

English as a Foreign Language is implemented as the compulsory subject to learn in senior high schoolsin Indonesia. The aim of the implementation is to achieve the informational level of literacy which is expected from students to be able to use English to access accumulated knowledge and use English in informal and formal contexts.

Unfortunately, beyond the implementation, the fact that not all pupils enjoy learning English occurs. Besides the students should face a new language for them to learn, the existing teaching style which merely transfers knowledge contributes to the stressful environment in class. The classroom environment contributes to the success of students' understanding of the lessons. It will not be easy for students who are in a stressful and boring environment to comprehend the lesson. If they are bored, unconsciously, they will resist any lesson.

Realizing that fact, teacher should find a strategy to attract students' attention to learn EFL, for example by using English movies. Moreover, using English movies to teach English is fun. In the application, teacher can use English movies to teach four language skills. They include reading, listening, speaking, and also writing skills. By using English movies, teacher can also teach grammar and introduce new vocabulary to students. Furthermore, the belief that everyone loves watching movies strengthens the teacher's confidence to use English movies as an attractive strategy to teach English as a Foreign Language to senior high schoolstudents.

\section{REFERENCES}

http: / / www.eslcafe.com/idea/index. cgi?display:998385852-2522.txt

http://www.eslpartyland.com/teachers/ film/previews.htm

http: / / www.ierg.net/confs / 2004 / Proceedings/Kusumarasdyati.pdf

http://www.teflasia.com/teacher-talk/ using-movies-in-the-classroom/

http: / / www.tefllogue.com / in-theclassroom/everybody-loves-movies. html

http: //www.tefllogue.com/in-theclassroom/using-movies-inclasswithout-sound.html 